\title{
Strategies for improving the solubility and metabolic stability of griseofulvin analogues
}

Petersen, Asger Bjørn; Konotop, G.; Hanafiah, N. H. M.; Hammershøj, Peter; Raab, M. S.; Kraemer, A.; Clausen, Mads Hartvig

Published in:

European Journal of Medicinal Chemistry

Link to article, DOI:

10.1016/j.ejmech.2016.03.071

Publication date:

2016

Document Version

Peer reviewed version

Link back to DTU Orbit

Citation (APA):

Petersen, A. B., Konotop, G., Hanafiah, N. H. M., Hammershøj, P., Raab, M. S., Kraemer, A., \& Clausen, M. H. (2016). Strategies for improving the solubility and metabolic stability of griseofulvin analogues. European Journal of Medicinal Chemistry, 116, 210-215. https://doi.org/10.1016/j.ejmech.2016.03.071

\section{General rights}

Copyright and moral rights for the publications made accessible in the public portal are retained by the authors and/or other copyright owners and it is a condition of accessing publications that users recognise and abide by the legal requirements associated with these rights.

- Users may download and print one copy of any publication from the public portal for the purpose of private study or research.

- You may not further distribute the material or use it for any profit-making activity or commercial gain

- You may freely distribute the URL identifying the publication in the public portal 


\title{
Strategies for Improving the Solubility and Metabolic Stability of Griseofulvin Analogues
}

A. B. Petersen, ${ }^{a}$ G. Konotop, ${ }^{b}$ N. H. M. Hanafiah, ${ }^{b}$ P. Hammersh $\varnothing j,{ }^{a}$ M. S. Raab, ${ }^{b}$ A. Krämer, ${ }^{c}$ and M. H. Clausen ${ }^{a}$

\author{
a. Center for Nanomedicine and Theranostics \& Department of Chemistry, Technical University of \\ Denmark, Kemitorvet 207, DK-2800 Kgs. Lyngby, Denmark. \\ b. Max-Eder Group Experimental Therapies for Hematologic Malignancies, German Cancer Research \\ Center (DKFZ). \\ c. Clinical Cooperation Unit Molecular Hematology/Oncology, German Cancer Research Center (DKFZ) \\ and Dept. of Internal Medicine V, University of Heidelberg, Heidelberg, Germany.
}

\begin{abstract}
We report two types of modifications to the natural product griseofulvin as strategies to improve solubility and metabolic stability: the conversion of aryl methyl ethers into aryl difluoromethyl ethers at metabolic hotspots and the conversion of the C-ring ketone into polar oximes. The syntheses of the analogues are described together with their solubility, metabolic half-life in vitro and antiproliferative effect in two cancer cell lines. We conclude that on balance, the formation of polar oximes is the most promising strategy for improving the properties of the analogues.
\end{abstract}

\section{Introduction}

Griseofulvin 1 was one of the first antifungal natural products found and isolated in filamentous fungi. ${ }^{1}$ It has since its discovery in 1939 attracted a lot of attention due to its bioactivity. The first report of griseofulvin's potential for the treatment of ringworm in man was published in 1958 and griseofulvin was launched as a human and veterinary drug for this indication under the trade names Fulcin and Grisovin. ${ }^{2,3}$ Since griseofulvin's discovery more than 400 analogues have been prepared and reported in the literature. ${ }^{4}$ In 2001 it was demonstrated that griseofulvin could potentiate the antitumorigenic effect of the drug Nocodazole by inducing apoptosis in several cancer cell lines at concentrations down to $1 \mu \mathrm{M}$. $^{5} \mathrm{Griseofulvin}$ has been shown to interfere with tubulin polymerization and microtubule dynamics. ${ }^{6,7}$ In 2006 , it was shown that structural modification of griseofulvin could improve cytotoxicity against cancer cells and in 2007 it was reported that spirobenzofuranones can inhibit centrosomal clustering - a strategy of many cancer cell lines harbouring supernumerary centrosomes to avoid lethal multipolar cell divisions. ${ }^{8,9} \mathrm{~A}$ subsequent anticancer SAR study of 34 compounds identified the 2'-benzyl derivative 2 (GF-15) as one of the most potent analogues. ${ }^{10}$ A more detailed study was performed on $\mathbf{2}$ including in vivo studies in murine xenograft models of colon cancer and multiple myeloma. ${ }^{11}$ Here we report the in vitro metabolic stability of $\mathbf{1}$ and $\mathbf{2}$ as well as the synthesis of two analogues with a group known to block metabolism at hotspots for CYP oxidation of griseofulvin: the 4 and the 6 positions (see Figure 1 ). ${ }^{12-14}$ 

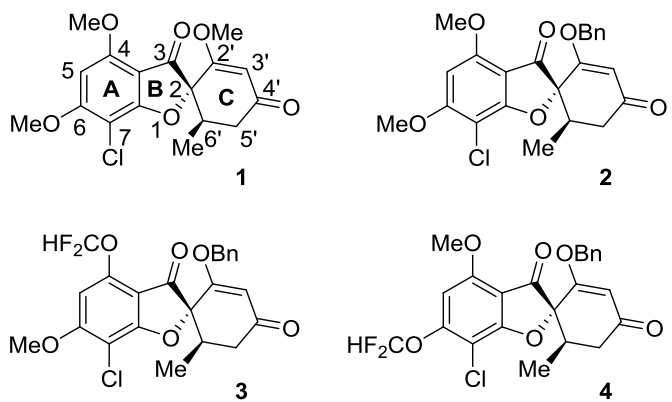

Fig. 1 Chemical structure of griseofulvin 1 with the IUPAC recommended numbering and ring designation and structure of 2'-benzyl modified lead compound 2. Furthermore, structures of 4-difluoro (3) and 6difluoro (4) modified analogues of $\mathbf{2}$, proposed to improve metabolic stability.

\section{Improving Metabolic Stability of Griseofulvin Analogues}

Different major metabolites of $\mathbf{1}$ have been identified from published in vivo studies. The major metabolites in rat, mouse, dog and man were found to be 4-desmethyl griseofulvin (5) and 6-desmethyl griseofulvin. ${ }^{15-18}$ Both metabolites have previously been shown to have no (5) or low (6) antiproliferative activity against the cancer cell line MDA-MB-231. ${ }^{19}$ In order to increase the metabolic half-life of griseofulvin analogues such as 2, we wanted to block CYP oxidation at the two hotspots at position 4 and 6, respectively. The two aryl methyl ethers $\mathbf{3}$ and $\mathbf{4}$ were therefore chosen for studying the effect of metabolic blockers. We arrived at these specific modifications, because very few examples of $\mathrm{CF}_{3}{ }^{+}$trifluoromethylation of phenols via $\mathrm{S}_{\mathrm{N}} 1$ or $\mathrm{S}_{\mathrm{N}} 2$ mechanisms have been reported and the potential reactivity of monofluoromethyl derivatives towards strong nucleophiles led us to choose difluoromethyl ethers as metabolic blockers. ${ }^{20-23}$ Difluoromethylation of phenols have been reported in the literature using methyl chlorodifluoroacetate and a suitable base such as caesium or potassium carbonate..$^{24,25}$

\section{Results and Discussion}

\section{Synthesis}

For the syntheses of the 4- and 6-difluoro modified griseofulvins ( 3 and $\mathbf{4}$ ), our starting point was a strategy first described by Arkley et al. and Stephenson et al. (see Scheme 1). ${ }^{26,27}$ For the position 4 modified analogue, griseofulvin was demethylated with magnesium iodide resulting in $\mathbf{5}$ followed by difluoromethylation with methyl chlorodifluoroacetate and base yielding 6. Potassium carbonate performed best in this reaction and was therefore used throughout. Hydrolysis of $\mathbf{6}$ gave the griseofulvic acid derivative $\mathbf{7}$, which was chlorinated with phosphoryl chloride and lithium chloride to give $\mathbf{8}$ (with the 4'-chloro derivative as the major by-product, not shown). The 2'-chloro derivative 8 was subjected to benzyl alcohol and DBU, which after 1,4-addition/elimination resulted in the desired 4-difluoro modified compound 3. ${ }^{19}$ A slightly different strategy was required for the 6-difluoro modified analogue since no efficient, scalable method for direct position 6 demethylation has been reported in the literature. ${ }^{28}$ We slightly modified the route reported by Arkley et al. and hydrolysed griseofulvin to griseofulvic acid (9), which was demethylated with dilute sodium hydroxide yielding $\mathbf{1 0}$ and converted into the isogriseofulvin derivative $\mathbf{1 1}$ by acid catalysed 4'-methylation with methanol. The hereby protected $\mathbf{1 1}$ was difluoromethylated with methyl chlorodifluoroacetate and base resulting in 12, which in a sequence similar to the 4-difluoro derivative 6 was hydrolysed, 2'-chlorinated and 2'-benzylated to give the desired difluoro analogue 4. 


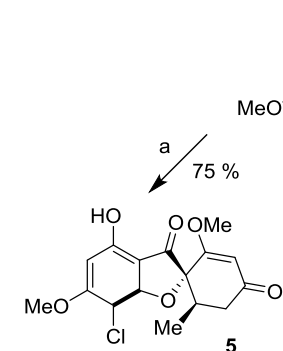

b $76 \%$

b 7

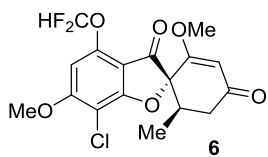

c $\ 97 \%$
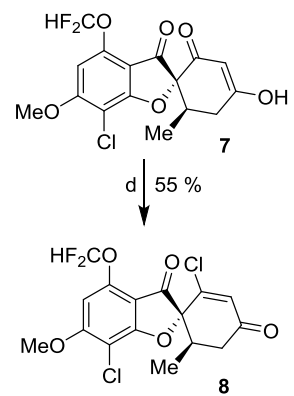

e $\downarrow 50 \%$

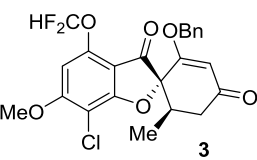

1 f $81 \%$

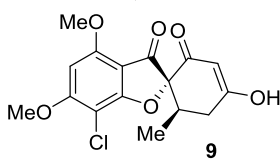

g $\downarrow 25 \%$

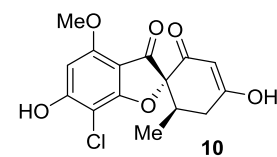

$\mathrm{h} \backslash 82 \%$

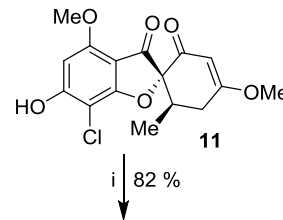

OMe

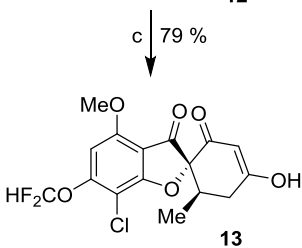

d $42 \%$

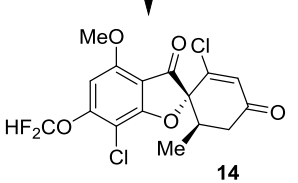

e $\downarrow 28 \%$

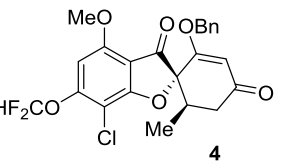

Scheme 1 Synthetic route for preparation of 4-difluoro (3) and 6-difluoro (4) modified 2'-benzyl griseofulvin analogues from griseofulvin (1). (a) $\mathrm{MgI}_{2}, \mathrm{Et}_{2} \mathrm{O}, \mathrm{PhH}$, reflux; (b) $\mathrm{K}_{2} \mathrm{CO}_{3}, \mathrm{ClF}_{2} \mathrm{CCO}_{2} \mathrm{Me}, \mathrm{DMF}, 70{ }^{\circ} \mathrm{C}$; (c) $\mathrm{H}_{2} \mathrm{SO}_{4}(2$ $\mathrm{M}), \mathrm{AcOH}, 80{ }^{\circ} \mathrm{C}$; (d) $\mathrm{LiCl}, \mathrm{POCl}_{3}, 1$,4-dioxane, $85^{\circ} \mathrm{C}$; (e) $\mathrm{BnOH}$, DBU, 1,4-dioxane, $60{ }^{\circ} \mathrm{C}$; (f) $\mathrm{H}_{2} \mathrm{SO}_{4}(1 \mathrm{M})$, $\mathrm{AcOH}, 100{ }^{\circ} \mathrm{C}$; (g) $\mathrm{NaOH}(0.7 \mathrm{M})$, reflux; (h) $\mathrm{CSA}$ (cat.), $\mathrm{MeOH}$, reflux; (i) $\mathrm{K}_{2} \mathrm{CO}_{3}, \mathrm{ClF}_{2} \mathrm{CCO}_{2} \mathrm{Me}, \mathrm{DMF}, 75^{\circ} \mathrm{C}$.

Two assays were used in order to investigate the compounds: 1) $I C_{50}$ against two established cancer cell lines and 2) microsomal stabilities against male mouse and rat microsomes. In order to obtain more SAR information, compounds 15 and $\mathbf{1 6}$ were included in the investigation (Fig. 2). Compound $\mathbf{1 5}$ has been reported previously ${ }^{19}$ and shown to have similar cytotoxicity as compound $\mathbf{2}$. Analogue $\mathbf{1 6}$ is reported here 
for the first time and was designed to increase the solubility in phosphate buffered saline (PBS) further. Both 15 and 16 are more polar compounds than 2, so they were expected to have lower oxidative metabolism.
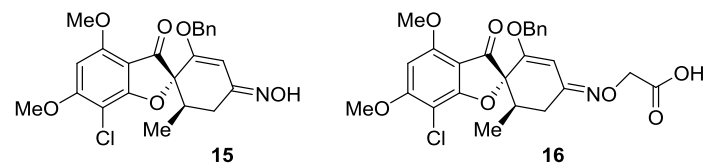

Fig. 2 Oxime analogues 15 and 16.

\section{Thermodynamic Solubility}

The thermodynamic solubility of 1-4, 15 and 16 was determined by HPLC: a reference absorption (peak area at $254 \mathrm{~nm}$ ) linear plot was made from a dilution series of the compounds in acetonitrile. Saturated PBS solutions of the compounds were prepared by sonication and shaking and the HPLC chromatogram peak areas were used to calculate the respective solubility from the reference graphs.

Table 1 Measured PBS solubility of the compounds investigated.

$\begin{array}{llc}\text { Entry } & \text { Compound } & \begin{array}{c}\text { Solubility } \\ (\mu \mathrm{g} / \mathrm{mL})\end{array} \\ 1 & 1 & 7.7 \\ 2 & 2 & 0.3 \\ 3 & 3 & <0.3^{\mathrm{a}} \\ 4 & 4 & <0.3^{\mathrm{a}} \\ 5 & 15 & 3.0 \\ 6 & 16 & >1000.0\end{array}$

${ }^{\mathrm{a}}$ Below the detection limit of the HPLC setup using the described assay.

Griseofulvin (1) is known to have low solubility (Table 1, entry 1 ) and compound $\mathbf{2}$ is highly lipophilic and has lower solubility in PBS (entry 2). As expected, modification by introducing fluorine substitution only aggravates this property (entries 3 and 4). However, this can be improved either somewhat through the 
formation of a simple oxime (entry 5) or quite dramatically by formation of the charged oxime $\mathbf{1 6}$ (entry 6), where the PBS solubility is higher than $1 \mathrm{mg} / \mathrm{mL}$. We have previously shown that oximes of griseofulvin are hydrolysed only very slowly and as such oxime formation presents a possible solution to issues of low solubility, provided that the potency is not negated. ${ }^{19}$

\section{Microsomal Stability}

Male mouse and male rat microsomes were purchased from a major supplier and NADPH was used as a cofactor. The experiments for each compound were run in triplicates, each with a control where no cofactor was added. At the indicated times samples were taken and the amount of non-degraded compound was quantified by analytical HPLC (peak area). Half-life was calculated from linear plots (see supporting information) and $t_{1 / 2}$ times are given in Table 2.

Table 2 Microsomal stability

$\begin{array}{llll}\text { Entry } & \text { Compound } & \begin{array}{l}\mathrm{t} 1 / 2 \\ (\text { Mouse) }\end{array} & \mathrm{t}^{\mathrm{b}} \frac{2}{2} \text { (Rat }^{\mathrm{b}} \\ 1 & 1 & 37 & 58 \\ 2 & 2 & 27 & 60^{\mathrm{a}} \\ 3 & 3 & 11 & 26 \\ 4 & 4 & 31 & 53 \\ 5 & 15 & 45 & 57 \\ 6 & 16 & 339 & 449\end{array}$

${ }^{a}$ Duplicate experiment. ${ }^{b}$ Stability against male liver microsomes, $t 1 / 2$ (min.)

To verify that no $2^{\prime}-\mathrm{CH}_{3}$ cleavage was performed by the mouse and rat microsomes a control experiment was performed. Deutorated griseofulvin $\mathbf{1 8}$ was prepared as shown in Scheme 2 and treated with mouse and rat microsomes respectively, and only position $4 / 6 \mathrm{CH}_{3}$ cleavage was observed by LC-MS.

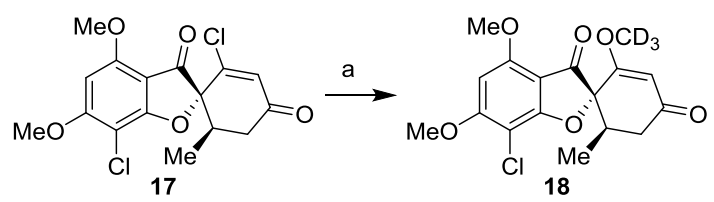

Scheme 2 Synthetic route for preparation of the deutorated compound 18. (a) I) $C D_{3} O D$, $D B U, 1,4$-dioxane, $\mathrm{RT}$, II) $\mathrm{MeOH}, \mathrm{DBU}$, reflux. 
As evident from Table 2, the introduction of metabolic blockers at position 4 or 6 had either a negative influence on half-life (3, entry 3 ) or no noticeable effect (4, entry 4$)$. The simple oxime $\mathbf{1 5}$ had a microsomal profile similar to the parent analogue (entry 5), while the more hydrophilic derivative $\mathbf{1 6}$ displayed an approximately 10 -fold increase in half-life for both species (entry 6).

\section{Anticancer potency}

The small molecule griseofulvin has a demonstrated in vitro activity against cancer cell lines with $\mathrm{IC}_{50}$ values ranging from $35 \mu \mathrm{M}$ in SCC114 cells to $75 \mu \mathrm{M}$ in HeLa cells but only little effect on non-cancerous cell lines at these concentrations. ${ }^{9}$ Further chemical optimization of griseofulvin led to the isolation of homologues with much lower mean inhibitory concentrations for proliferation and survival towards cancer cells. One of the most potent analogues was compound2, with more than 10 -fold lower $\mathrm{IC}_{50}$ values than griseofulvin in SCC114 cells. Additional in vitro studies revealed that $\mathbf{2}$ was 10 to 30 -fold more selective towards malignant cells, including multiple myeloma, leukaemia and a variety of solid tumours, when compared to healthy cells. ${ }^{12}$ We asked how the modifications aimed at increasing either the stability towards CYPs metabolism (3 and 4) or solubility in PBS (15 and 16) would affect the antitumour activity of these analogues in comparison to griseofulvin (1) and compound 2. To this end, we determined the antiproliferative activity towards the human epithelial breast cancer cell line MDA-MB231 and the human osteosarcoma U2OS cell line. The $I_{50}$ values (viable cells, luminescent assay for ATP, see supporting information) are reported in Table 3.

Table 3 Cytotoxicity of griseofulvin and analogues towards two cancer cell lines.

\begin{tabular}{|c|c|c|c|}
\hline Entry & Compound & $\begin{array}{l}\text { MDA-MB231 } \\
(\mu \mathrm{M})\end{array}$ & $\mathrm{U} 2 \mathrm{OS}(\mu \mathrm{M})$ \\
\hline 1 & 1 & $25.33 \pm 3.33$ & $\begin{array}{l}22.44 \pm \\
1.44\end{array}$ \\
\hline 2 & 2 & $1.62 \pm 0.54$ & $1.45 \pm 0.19$ \\
\hline 3 & 3 & $11.77 \pm 1.30$ & $\begin{array}{l}14.32 \pm \\
3.83\end{array}$ \\
\hline 4 & 4 & $5.34 \pm 1.38$ & $5.56 \pm 0.13$ \\
\hline 5 & 15 & $1.29 \pm 0.22$ & $1.61 \pm 0.40$ \\
\hline 6 & 16 & $10.10 \pm 2.59$ & $\begin{array}{l}14.13 \pm \\
3.83\end{array}$ \\
\hline
\end{tabular}


The known compounds $\mathbf{2}$ and $\mathbf{1 5}$ are most potent against both cell lines and, as previously demonstrated, both are significantly more potent than the parent griseofulvin (1) (Table 3, entries 1, 2 and 6).,90,19 Introduction of fluorine at the 4-position (entry 3) leads to a 10-fold reduction of cytotoxicity, suggesting a significant effect of the two fluorine atoms. For the 6-position, the reduction of potency is less dramatic (entry 4). We have previously shown that both demethylation and extension at positions 4 and 6 leads to reduced anti-cancer activity for griseofulvin analogues. ${ }^{19}$ The fact that even the modest structural changes described here affects potency, indicates a rather selective interaction between the target and the methoxy-substituted arene in griseofulvins. The difluoromethyl group is a known hydrogen bond donor and alcohol isostere, however, the $\mathrm{HF}_{2} \mathrm{C}$ hydrogen bond is considered very weak $(1.5 \mathrm{Kcal} / \mathrm{mol}){ }^{29-31}$ Nonetheless, for the 4-position, the neighbouring B-ring ketone could interact with fluorine in compound $\mathbf{3}$, which could change the conformation of the substituent. For analogue 4 , it is harder to explain the decrease in potency, besides from invoking the slightly larger size of the difluoromethyl group when compared to the methyl substituent.

As previously observed, formation of the simple oxime (15, entry 5) does not change potency. ${ }^{19}$ However, when the size of the 4' substituent increases, the cytotoxicity decreases (entry 6). This could be due to an unfavourable steric or charge interaction from the carboxymethyl group on the oxime. The highly increased polarity of $\mathbf{1 6}$ compared to $\mathbf{2}$ or $\mathbf{1 5}$ could also lead to decreased permeability and/or a lower affinity for the target.

\section{Discussion}

Metabolism of griseofulvin is known to go through position 4 and 6 demethylation. Our attempts to block metabolism at one site appears to have simply re-routed the main metabolic reaction to the non-blocked position. In order to increase metabolic half-life using this strategy, it would appear that one would need to modify both the 4- and the 6-position. However, given the lengthy synthetic routes involved and the decreased anti-cancer activity observed for $\mathbf{3}$ and $\mathbf{4}$ when compared to $\mathbf{2}$, this is not an attractive strategy. A more viable solution comes from rendering the compounds more polar, which both increases solubility (Table 1, entries 5 and 6) and half-life (Table 3, entry 6), with unchanged or only moderately decreased potency (Table 2, entries 5 and 6).

\section{Conclusions}

Griseofulvin analogues have interesting properties related to cancer biology and potential as small molecule therapeutics in oncology. However, the physico-chemical properties of these compounds are not germane to further drug development as they suffer from low aqueous solubility and modest microsomal stability. We have investigated two strategies aimed at ameliorating one or both of these problems: the introduction of metabolic blockers at two hotspots and the introduction of oximes to increase polarity. Results show that between these two approaches, increasing polarity has the greatest potential for providing candidates for further development. Future efforts should aim at improving potency while retaining good solubility and long half-lives. 


\section{Experimental}

\section{General}

For reactions carried out under argon the glassware was dried before use, employing the following procedure: heating was applied with a heat gun while the glassware was evacuated (16 Torr), the evacuation was followed by argon flushing. Evacuation and flushing were applied several times under continuous heating, and finally the glassware was allowed to cool to room temperature under argon before use. All reagents were purchased from major suppliers and used without further purification, unless otherwise noted. All solvents were analytical grade and dried when necessary over $4 \AA$ activated molecular sieves and water content was determined to be less than 20 ppm by Karl Fischer titration on a Metrohm 899 - Coulometer. Thin Layer Chromatography (TLC) was carried out on commercially available pre-coated plates (Merck 60, F254). Dry Column Vacuum Chromatography (DCVC) was performed according to a published procedure. ${ }^{32}$ When concentrating on Celite in vacuo for DCVC purification, high vacuum was also used. ${ }^{1} \mathrm{H},{ }^{13} \mathrm{C}, \mathrm{HSQC}$, and $\mathrm{HMBC}$ NMR spectra were recorded on a Bruker Ascend 400 Fourier transform spectrometer using an internal deuterium lock. ${ }^{19} \mathrm{~F}$ NMR Spectra were recorded on a Varian Mercury $300 \mathrm{~B}$ Fourier transform spectrometer. Solvents were used as internal standards when assigning ${ }^{1} \mathrm{H}$ and ${ }^{13} \mathrm{C} \mathrm{NMR}$ spectra ( $\delta \mathrm{H}: ~^{\mathrm{CHCl}_{3}} 7.26$ ppm, DMSO- $d_{5} 2.50 ; \delta \mathrm{C}: \mathrm{CDCl}_{3} 77.16 \mathrm{ppm}$, DMSO- $d_{6} 39.52 \mathrm{ppm}$ ). For $E / Z$ isomer mixtures, chemical shifts for the minor isomer are given in brackets. Purity by HPLC was performed on a Waters e2629 separation module fitted with a Waters 2998 photo diode array detector using a Waters Symmetry $3.5 \mu \mathrm{m}$ C18 column $(4.6 \times 75 \mathrm{~mm})$ employing a 2 solvent system consisting of solvent A: water and solvent $B$ : acetonitrile (both solvents containing $0.1 \%$ formic acid). HRMS was performed on a Bruker Daltonics maXis 3G QTOF-MS fitted with a Dionex Ultimate 3000 UHPLC. A Stuart Advanced Digital Melting Point SMP30 was used to determine melting point and they are reported uncorrected. Optical rotation was measured on a Perkin-Elmer 241 Polarimeter, and the values are given in degrees and concentrations are given as g/100 mL. Compounds 2, 5, 9 and 15 ( $E / Z$ mixture) were synthesised according to literature procedures while $\mathbf{1 0}$ and $\mathbf{1 1}$ were synthesised using modified literature procedures. ${ }^{11,27,29}$ For 10: $0.7 \mathrm{M}$ $\mathrm{NaOH}$ was used instead of $0.5 \mathrm{M} \mathrm{NaOH}$ and for 11: CSA and $\mathrm{MeOH}$ was used instead of $(\mathrm{MeO})_{2} \mathrm{CHMe}_{2}$ and p-TSA followed by $\mathrm{HCl}$ (conc.) for acetal cleavage.

(2S,6'R)-2'-(Benzyloxy)-7-chloro-4-(difluoromethoxy)-6-methoxy-6'-methyl-3H-spiro[benzofuran-2,1'cyclohexan]-2'-ene-3,4'-dione (3). To a stirred solution of $8(0.20 \mathrm{~g}, 0.50 \mathrm{mmol})$ in 1,4-dioxane $(3 \mathrm{~mL})$ under argon was added benzyl alcohol $(0.11 \mathrm{~mL}, 1.0 \mathrm{mmol})$ followed by DBU $(0.19 \mathrm{~mL}, 1.25 \mathrm{mmol})$. The solution was heated to $60^{\circ} \mathrm{C}$, after $20 \mathrm{~h}$. the reaction was cooled to $22^{\circ} \mathrm{C}$, celite was added and the mixture was concentrated in vacuo. Purification by DCVC $(\varnothing=20 \mathrm{~mm})$ gradient eluting from $100 \%$ toluene $\rightarrow 75 / 25$ toluene / acetonitrile with $2.5 \%$ increment / $20 \mathrm{~mL}$ fraction and recrystallization from toluene / heptane yielded $0.16 \mathrm{~g}$ (50\%) 3 as white crystals. $R_{\mathrm{f}}=0.31$ (90/10, toluene / acetonitrile); Mp. $113-114{ }^{\circ} \mathrm{C} ;[\alpha]_{D}^{20}=$ $+177^{\circ}\left(c=0.25, \mathrm{CHCl}_{3}\right) ;{ }^{1} \mathrm{H}$ NMR $\left(400 \mathrm{MHz}, \mathrm{CDCl}_{3}\right) \delta 7.33-7.24(3 \mathrm{H}, \mathrm{m}), 7.15(2 \mathrm{H}, \mathrm{dd}, J=7.4 \& 1.8 \mathrm{~Hz}), 6.91$ $\left(1 \mathrm{H}, \mathrm{t},{ }^{2} J_{\mathrm{HF}}=73.5 \mathrm{~Hz}\right), 6.47(1 \mathrm{H}, \mathrm{s}), 5.62(1 \mathrm{H}, \mathrm{s}), 4.89(2 \mathrm{H}, \mathrm{AB}, J=12.3 \mathrm{~Hz}, \Delta=33.7 \mathrm{~Hz}), 4.01(3 \mathrm{H}, \mathrm{s}), 2.98(1 \mathrm{H}$, $\mathrm{dd}, J=16.1$ \& $13.3 \mathrm{~Hz}), 2.94-2.84(1 \mathrm{H}, \mathrm{m}), 2.46(1 \mathrm{H}, \mathrm{dd}, J=16.1 \& 4.0 \mathrm{~Hz}), 0.98(3 \mathrm{H}, \mathrm{d}, J=6.5 \mathrm{~Hz}) ;{ }^{13} \mathrm{C} \mathrm{NMR}$ $\left(101 \mathrm{MHz}, \mathrm{CDCl}_{3}\right) \delta 196.6,192.6,169.5,168.9,164.2,146.9\left(\mathrm{t},{ }^{3} \mathrm{JF}_{\mathrm{CF}}=3.7 \mathrm{~Hz}\right), 134.6,128.8,128.5,126.9$, $115.6\left(\mathrm{t},{ }^{1} J_{\mathrm{CF}}=265.4 \mathrm{~Hz}\right), 107.2,106.4,102.4,98.9,91.3,71.0,57.5,40.1,36.5,14.4 ;{ }^{19} \mathrm{~F} \mathrm{NMR}(282 \mathrm{MHz}$, $\left.\mathrm{CDCl}_{3}\right) \delta-83.93\left(2 \mathrm{~F}, \mathrm{ABX},{ }^{2} J_{\mathrm{FF}}=163.8 \mathrm{~Hz} \&{ }^{2} J_{\mathrm{FH}}=73.5 \mathrm{~Hz}\right) ; \mathrm{HRMS}\left(\mathrm{ESI}^{+}\right) 465.0916$ calcd. for $\left[\mathrm{M}+\mathrm{H}^{+}\right] 465.0911$. 
(2S,6'R)-2'-(Benzyloxy)-7-chloro-6-(difluoromethoxy)-4-methoxy-6'-methyl-3H-spiro[benzofuran-2,1'cyclohexan]-2'-ene-3,4'-dione (4). To a stirred solution of 14 (0.20 g, $0.50 \mathrm{mmol})$ in 1,4-dioxane ( $3 \mathrm{~mL})$ under argon was added benzyl alcohol $(0.11 \mathrm{~mL}, 1.0 \mathrm{mmol})$ followed by DBU $(0.19 \mathrm{~mL}, 1.25 \mathrm{mmol})$. The solution was heated to $60^{\circ} \mathrm{C}$, after $20 \mathrm{~h}$. the reaction was cooled to $22^{\circ} \mathrm{C}$, celite was added and the mixture was concentrated in vacuo. Purification by DCVC $(\varnothing=20 \mathrm{~mm})$ gradient eluting from $100 \%$ toluene $\rightarrow 75 /$ 25 , toluene / acetonitrile with $2.5 \%$ increment / $20 \mathrm{~mL}$ fraction yielded $0.065 \mathrm{~g}(28 \%) 4$ as white crystals. $R_{\mathrm{f}}$ $=0.16\left(90 / 10\right.$, toluene / acetonitrile); Mp. 109-112 ${ }^{\circ} \mathrm{C} ;[\alpha]_{D}^{20}=+147^{\circ}\left(c=0.5, \mathrm{CHCl}_{3}\right) ;{ }^{1} \mathrm{H} \mathrm{NMR}(400 \mathrm{MHz}$, $\left.\mathrm{CDCl}_{3}\right) \delta$ 7.35-7.24 $(3 \mathrm{H}, \mathrm{m}), 7.20-7.11(2 \mathrm{H}, \mathrm{m}), 6.66\left(1 \mathrm{H}, \mathrm{t},{ }^{2} J_{\mathrm{HF}}=72.1 \mathrm{~Hz}\right), 6.39(1 \mathrm{H}, \mathrm{s}), 5.61(1 \mathrm{H}, \mathrm{s}), 4.88(2 \mathrm{H}$, $A B, J=12.3 \& 39.8 \mathrm{~Hz}), 3.95(3 \mathrm{H}, \mathrm{s}), 3.03(1 \mathrm{H}, \mathrm{dd}, J=16.5 \& 13.3 \mathrm{~Hz}), 2.95-2.83(1 \mathrm{H}, \mathrm{m}), 2.47(1 \mathrm{H}, \mathrm{dd}, J=$ 16.5 \& 4.4 Hz), $1.00(3 \mathrm{H}, \mathrm{d}, J=6.7 \mathrm{~Hz}) ;{ }^{13} \mathrm{C} \mathrm{NMR}\left(101 \mathrm{MHz}, \mathrm{CDCl}_{3}\right) \delta 196.7,193.3,170.2,168.9,157.0,155.9$ $\left(\mathrm{t},{ }^{3} J_{\mathrm{CF}}=2.6 \mathrm{~Hz}\right), 134.6,128.8,128.5,126.7,115.33\left(\mathrm{t},{ }^{1} J_{\mathrm{CF}}=265 \mathrm{~Hz}\right), 108.8,106.3,101.8,97.5,91.4,71.0$, 56.8, 40.1, 36.4, 14.5; ${ }^{19} \mathrm{~F} \mathrm{NMR}\left(282 \mathrm{MHz}, \mathrm{CDCl}_{3}\right) \delta-82.14\left(2 \mathrm{~F}, \mathrm{~d}^{2}{ }^{2} \mathrm{JFH}_{\mathrm{FH}}=72.1 \mathrm{~Hz}\right) ; \mathrm{HRMS}\left(\mathrm{ESI}^{+}\right) 465.0928$ calcd. for $\left[\mathrm{M}+\mathrm{H}^{+}\right] 465.0911$.

\section{(2S,6'R)-7-Chloro-4-(difluoromethoxy)-2',6-dimethoxy-6'-methyl-3H-spiro[benzofuran-2,1'-cyclohexan]-}

2'-ene-3,4'-dione (6). To a stirred solution of 5 (5.80 g, $17 \mathrm{mmol})$ in DMF (50 mL) under argon was added potassium carbonate $(2.35 \mathrm{~g}, 17 \mathrm{mmol})$ followed by methyl chlorodifluoroacetate $(2.46 \mathrm{~mL}, 23 \mathrm{mmol})$. After $18 \mathrm{~h}$. at $70{ }^{\circ} \mathrm{C}$ the reaction was cooled to $22{ }^{\circ} \mathrm{C}$ before being poured into $100 \mathrm{~mL} 1 / 4$ saturated sodium carbonate. The resulting precipitate was isolated, dissolved in dichloromethane and concentrated on celite in vacuo. Purification by DCVC ( $\varnothing=60 \mathrm{~mm}$ ) gradient eluting from $100 \%$ heptane $\rightarrow 100 \%$ ethyl acetate with $10 \%$ increment $/ 100 \mathrm{~mL}$ fraction yielded $5.1 \mathrm{~g}(76 \%) 6$ as white powder. $R_{\mathrm{f}}=0.60$ (ethyl acetate); $[\alpha]_{D}^{20}=+275^{\circ}\left(c=0.25, \mathrm{CHCl}_{3}\right) ;{ }^{1} \mathrm{H} \mathrm{NMR}\left(400 \mathrm{MHz}, \mathrm{CDCl}_{3}\right) \delta 6.89\left(1 \mathrm{H}, \mathrm{t}^{2}{ }^{2} \mathrm{HF}_{\mathrm{HF}}=73.3 \mathrm{~Hz}\right), 6.48(1 \mathrm{H}, \mathrm{s}), 5.54(1 \mathrm{H}$, s), $4.00(3 \mathrm{H}, \mathrm{s}), 3.62(3 \mathrm{H}, \mathrm{s}), 2.93(1 \mathrm{H}, \mathrm{dd}, J=16.1 \& 13.3 \mathrm{~Hz}), 2.89-2.78(1 \mathrm{H}, \mathrm{m}), 2.43(1 \mathrm{H}, \mathrm{dd}, J=16.1 \& 4.0$ $\mathrm{Hz}), 0.92(3 \mathrm{H}, \mathrm{d}, J=6.5 \mathrm{~Hz}) ;{ }^{13} \mathrm{C}$ NMR $\left(101 \mathrm{MHz}_{\mathrm{CDCl}}\right) \delta 196.7,192.5,170.3,169.4,164.2,147.0\left(\mathrm{t},{ }^{3} \mathrm{~J}_{\mathrm{CF}}=3.7\right.$ $\mathrm{Hz}), 115.5\left(\mathrm{t},{ }^{1} J_{\mathrm{CF}}=265.2 \mathrm{~Hz}\right), 106.9,105.1,102.3,98.6,91.1,57.5,56.9,39.9,36.5,14.2 ;{ }^{19} \mathrm{~F} \mathrm{NMR}(282 \mathrm{MHz}$, $\left.\mathrm{CDCl}_{3}\right) \delta-83.90\left(2 \mathrm{~F}, \mathrm{ABX},{ }^{2} J_{\mathrm{FF}}=164.0 \mathrm{~Hz} \&^{2} \mathrm{~J}_{\mathrm{FH}}=73.5 \mathrm{~Hz}\right) ; \mathrm{HRMS}\left(\mathrm{ESI}^{+}\right) 389.0594$ calcd. for $\left[\mathrm{M}+\mathrm{H}^{+}\right] 389.0598$.

(2S,6'R)-7-Chloro-4-(difluoromethoxy)-4'-hydroxy-6-methoxy-6'-methyl-3H-spiro[benzofuran-2,1'cyclohexan]-3'-ene-2',3-dione (7). To a stirred solution of $6(2.9 \mathrm{~g}, 7.5 \mathrm{mmol})$ in acetic acid (20 mL) was added sulfuric acid $(6 \mathrm{~mL}, 2 \mathrm{M})$, the solution was heated to $80^{\circ} \mathrm{C}$. After $45 \mathrm{~min}$. the solution was cooled to $22{ }^{\circ} \mathrm{C}$ before being poured into water $(150 \mathrm{~mL})$. The resulting precipitate was isolated and extracted extensively with water yielding $2.7 \mathrm{~g}(97 \%) 7$ as light yellow powder. A sample was recrystallised from ethyl acetate/heptane yielding light yellow crystals. Mp. $205-208{ }^{\circ} \mathrm{C}(\mathrm{dec}$. $) ;[\alpha]_{D}^{20}=+234^{\circ}(c=0.25, \mathrm{MeOH}) ;{ }^{1} \mathrm{H}$ NMR $\left(400 \mathrm{MHz}, \mathrm{DMSO}-d_{6}\right) \delta 12.00(1 \mathrm{H}, \mathrm{bs}), 7.46\left(1 \mathrm{H}, \mathrm{t},{ }^{2} \mathrm{~J}_{\mathrm{HF}}=72.8 \mathrm{~Hz}\right), 6.74(1 \mathrm{H}, \mathrm{s}), 5.33(1 \mathrm{H}, \mathrm{s}), 4.03(3 \mathrm{H}, \mathrm{s})$, 2.89-2.75 $(2 \mathrm{H}, \mathrm{m}), 2.60-2.51(1 \mathrm{H}, \mathrm{m}), 0.88(3 \mathrm{H}, \mathrm{d}, J=5.9 \mathrm{~Hz}) ;{ }^{13} \mathrm{C} \mathrm{NMR}\left(101 \mathrm{MHz}, \mathrm{DMSO}-d_{6}\right) \delta 191.2,187.0$, $179.8,168.9,163.7,147.4\left(\mathrm{t},{ }^{3} J_{\mathrm{CF}}=4.1 \mathrm{~Hz}\right), 115.9\left(\mathrm{t},{ }^{1} J_{\mathrm{CF}}=259.9 \mathrm{~Hz}\right), 105.7,101.1,99.9,96.8,95.2,58.0$, 34.4, 32.7, 14.2; ${ }^{19} \mathrm{~F}$ NMR $\left(282 \mathrm{MHz}\right.$, DMSO- $\left.d_{6}\right) \delta-84.64\left(2 \mathrm{~F}, \mathrm{~d},{ }^{2} J_{\mathrm{FH}}=72.8 \mathrm{~Hz}\right)$; HRMS $\left(\mathrm{ESI}^{+}\right) 375.0444$ calcd. for $\left[\mathrm{M}+\mathrm{H}^{+}\right] 375.0441$.

(2R,6'R)-2',7-Dichloro-4-(difluoromethoxy)-6-methoxy-6'-methyl-3H-spiro[benzofuran-2,1'-cyclohexan]2'-ene-3,4'-dione (8). To a stirred solution of 7 (1.0 g, $2.7 \mathrm{mmol})$ in 1,4-dioxane $(10 \mathrm{~mL})$ was added lithium chloride $\left(1.0 \mathrm{~g}, 24 \mathrm{mmol}\right.$ ) and phosphoryl trichloride $(5 \mathrm{~mL})$. The mixture was heated to $85^{\circ} \mathrm{C}$ for $40 \mathrm{~min}$. before cooling with ice bath (carefully, not frozen). Saturated sodium carbonate was added (slowly) until the $\mathrm{pH}$ reached 8 and the mixture was extracted with dichloromethane $(3 \times 30 \mathrm{~mL})$. The combined organic 
extracts were dried with sodium sulfate before celite was added and the mixture was concentrated in vacuo. Purification by DCVC $(\varnothing=40 \mathrm{~mm})$ gradient eluting from $100 \%$ toluene $\rightarrow 90 / 10$, toluene / acetonitrile with $1 \%$ increment / $50 \mathrm{~mL}$ fraction (each gradient run with $2 \times 50 \mathrm{~mL}$ ) yielded $0.58 \mathrm{~g} \mathrm{(55 \% )} 8$ as an uncoloured oil (the major side product was the $4^{\prime}$-chloro substituted analogue, not illustrated, of which was isolated $0.45 \mathrm{~g}(43 \%)) . R_{\mathrm{f}}=0.46\left(90 / 10\right.$, toluene / acetonitrile); $[\alpha]_{D}^{20}=+301^{\circ}\left(c=0.25, \mathrm{CHCl}_{3}\right)$; ${ }^{1} \mathrm{H}$ NMR $\left(400 \mathrm{MHz}, \mathrm{CDCl}_{3}\right) \delta 6.91\left(1 \mathrm{H}, \mathrm{t},{ }^{2} J_{\mathrm{HF}}=73.2 \mathrm{~Hz}\right), 6.53(1 \mathrm{H}, \mathrm{s}), 6.46(1 \mathrm{H}, \mathrm{s}), 4.04(3 \mathrm{H}, \mathrm{s}), 3.08(1 \mathrm{H}, \mathrm{dd}, J$ $=16.6 \& 13.9 \mathrm{~Hz}), 3.01-2.88(1 \mathrm{H}, \mathrm{m}), 2.50(1 \mathrm{H}, \mathrm{dd}, J 16.6 \& 4.2 \mathrm{~Hz}), 0.99(3 \mathrm{H}, \mathrm{d}, 6.6 \mathrm{~Hz}) ;{ }^{13} \mathrm{C} \mathrm{NMR}(101 \mathrm{MHz}$, $\left.\mathrm{CDCl}_{3}\right) \delta 194.2,191.1,169.0,164.6,151.8,147.0\left(\mathrm{t},{ }^{3} \mathrm{~J}_{\mathrm{CF}}=3.7 \mathrm{~Hz}\right), 131.7,115.5\left(\mathrm{t},{ }^{1} \mathrm{~J}_{\mathrm{CF}}=265.7 \mathrm{~Hz}\right), 107.0$, 102.5, 99.1, 91.9, 57.6, 40.0, 37.6, 14.9; ${ }^{19} \mathrm{~F} \mathrm{NMR}\left(282 \mathrm{MHz}, \mathrm{CDCl}_{3}\right) \delta-83.95\left(2 \mathrm{~F}, \mathrm{ABX},{ }^{2} \mathrm{~J}_{\mathrm{FF}}=163.5 \mathrm{~Hz} \&{ }^{2} J_{\mathrm{FH}}=\right.$ $72.1 \mathrm{~Hz}$ ); HRMS $\left(\mathrm{ESI}^{+}\right) 393.0099$ calcd. for $\left[\mathrm{M}+\mathrm{H}^{+}\right]$393.0103.

\section{(2S,6'R)-7-Chloro-6-(difluoromethoxy)-4,4'-dimethoxy-6'-methyl-3H-spiro[benzofuran-2,1'-cyclohexan]-}

3'-ene-2',3-dione (12). To a stirred solution of $11(2.0 \mathrm{~g}, 6.0 \mathrm{mmol})$ in DMF (50 mL) under argon was added potassium carbonate $(0.83 \mathrm{~g}, 6.0 \mathrm{mmol})$ followed by methyl chlorodifluoroacetate $(0.96 \mathrm{~mL}, 9.1 \mathrm{mmol})$. After $6 \frac{1}{2} \mathrm{~h}$. at $75{ }^{\circ} \mathrm{C}$ the reaction was cooled to $22^{\circ} \mathrm{C}$ before being poured into $50 \mathrm{~mL} 1 / 4$ saturated sodium carbonate. The resulting precipitate was isolated, dissolved in dichloromethane and concentrated on celite in vacuo. Purification by DCVC $(\varnothing=40 \mathrm{~mm}$ ) gradient eluting from $100 \%$ heptane $\rightarrow 100 \%$ ethyl acetate with $10 \%$ increment / $50 \mathrm{~mL}$ fraction yielded $1.9 \mathrm{~g}$ (82\%) 12 as white powder, a sample was recrystallised from dichloromethane / heptane. $R_{\mathrm{f}}=0.64$ (ethyl acetate); Mp. 160.0-161.0 ${ }^{\circ} \mathrm{C} ;[\alpha]_{D}^{20}=+160^{\circ}(c=0.25$, $\left.\mathrm{CHCl}_{3}\right) ;{ }^{1} \mathrm{H} \mathrm{NMR}\left(400 \mathrm{MHz}, \mathrm{CDCl}_{3}\right) \delta 6.65\left(1 \mathrm{H}, \mathrm{dd},{ }^{2} J_{\mathrm{HF}}=72.8 \& 72.0 \mathrm{~Hz}\right), 6.37(1 \mathrm{H}, \mathrm{s}), 5.44(1 \mathrm{H}, \mathrm{d}, J=1.4 \mathrm{~Hz})$, $3.92(3 \mathrm{H}, \mathrm{s}), 3.78(3 \mathrm{H}, \mathrm{s}), 3.18(1 \mathrm{H}, \mathrm{ddd}, J=17.6,12.0$ \& $1.4 \mathrm{~Hz}), 2.92-2.81(1 \mathrm{H}, \mathrm{m}), 2.49(1 \mathrm{H}, \mathrm{dd}, J=17.6$ \& $5.7 \mathrm{~Hz}), 1.03(3 \mathrm{H}, \mathrm{d}, 6.7 \mathrm{~Hz}) ;{ }^{13} \mathrm{C} \mathrm{NMR}\left(101 \mathrm{MHz}, \mathrm{CDCl}_{3}\right) \delta 192.5,187.9,179.1,170.4,157.0,155.8\left(\mathrm{t},{ }^{3} J_{\mathrm{CF}}=\right.$ $2.7 \mathrm{~Hz}), 115.4\left(\mathrm{dd},{ }^{1} J_{\mathrm{CF}}=265 \mathrm{~Hz}, 264 \mathrm{~Hz}\right), 108.8,102.1,99.6,97.4,95.8,56.7,56.5,35.3,33.0,14.7 ;{ }^{19} \mathrm{~F} \mathrm{NMR}$ $\left(282 \mathrm{MHz}, \mathrm{CDCl}_{3}\right) \delta-82.03\left(2 \mathrm{~F}, \mathrm{ABX},{ }^{2} J_{\mathrm{FF}}=164.4 \mathrm{~Hz} \&{ }^{2} J_{\mathrm{FH}}=72.4 \mathrm{~Hz}\right) ; \mathrm{HRMS}\left(\mathrm{ESI}^{+}\right) 389.0600$ calcd. for [M+H $\left.\mathrm{H}^{+}\right]$ 389.0598.

(2S,6'R)-7-Chloro-6-(difluoromethoxy)-4'-hydroxy-4-methoxy-6'-methyl-3H-spiro[benzofuran-2,1'cyclohexan]-3'-ene-2',3-dione (13). To a stirred solution of 12 (1.7 g, $4.4 \mathrm{mmol})$ in acetic acid (15 mL) was added sulfuric acid $(4 \mathrm{~mL}, 2 \mathrm{M})$, the solution was heated to $80^{\circ} \mathrm{C}$. After $45 \mathrm{~min}$. the solution was cooled to $22{ }^{\circ} \mathrm{C}$ before being poured into water $(50 \mathrm{~mL})$. The mixture was extracted ethyl acetate $(3 \times 40 \mathrm{~mL})$ and the combined organic extracts was dried with sodium sulfate before celite was added and it was concentrated in vacuo. Purification by DCVC $(\varnothing=40 \mathrm{~mm})$ gradient eluting from $100 \%$ heptane $\rightarrow 100 \%$ ethyl acetate with $10 \%$ increment / $50 \mathrm{~mL}$ fraction followed by ethyl acetate $(4 \times 50 \mathrm{~mL}$ ) (all solvents containing 0.2 vol\% acetic acid) yielded $1.3 \mathrm{~g}$ (79 \%) 13 as white powder, a sample was recrystallised from ethyl acetate / heptane. $R_{\mathrm{f}}=0.32\left(0.2 \%\right.$ acetic acid in ethyl acetate); Mp. $209-210{ }^{\circ} \mathrm{C}$ (dec.); $[\alpha]_{D}^{20}=+191^{\circ}(c=0.25$, $\mathrm{MeOH}) ;{ }^{1} \mathrm{H}$ NMR $\left(400 \mathrm{MHz}, \mathrm{DMSO}-d_{6}\right) \delta 11.98(1 \mathrm{H}, \mathrm{bs}), 7.56\left(1 \mathrm{H}, \mathrm{t},{ }^{2} J_{\mathrm{HF}}=72.3 \mathrm{~Hz}\right), 6.67(1 \mathrm{H}, \mathrm{s}), 5.31(1 \mathrm{H}, \mathrm{s})$, $3.90(3 \mathrm{H}, \mathrm{s}), 2.90-2.75(2 \mathrm{H}, \mathrm{m}), 2.59-2.50(1 \mathrm{H}, \mathrm{m}), 0.86(3 \mathrm{H}, \mathrm{d}, J=5.7 \mathrm{~Hz}) ;{ }^{13} \mathrm{C}$ NMR $\left(101 \mathrm{MHz}, \mathrm{DMSO}-d_{6}\right) \delta$ $191.9,186.8,179.8,169.4,156.8,155.8\left(\mathrm{t},{ }^{3} J_{\mathrm{CF}}=3.5 \mathrm{~Hz}\right), 116.1\left(\mathrm{t},{ }^{1} J_{\mathrm{CF}}=260.4 \mathrm{~Hz}\right), 107.4,101.2,98.6,96.0$, 94.9, 56.9, 34.3, 32.9, 14.2; ${ }^{19} \mathrm{~F}$ NMR $\left(282 \mathrm{MHz}, \mathrm{DMSO}-d_{6}\right) \delta-83.86\left(2 \mathrm{~F}, \mathrm{~d}^{2}{ }^{2} \mathrm{JFH}_{\mathrm{FH}}=72.3 \mathrm{~Hz}\right)$; HRMS $\left(\mathrm{ESI}{ }^{+}\right)$ 375.0461 calcd. for $\left[\mathrm{M}+\mathrm{H}^{+}\right] 375.0441$.

(2R,6'R)-2',7-Dichloro-6-(difluoromethoxy)-4-methoxy-6'-methyl-3H-spiro[benzofuran-2,1'-cyclohexan]2'-ene-3,4'-dione (14). To a stirred solution of $13(1.2 \mathrm{~g}, 3.2 \mathrm{mmol})$ in 1,4-dioxane (12 mL) was added lithium chloride $(1.2 \mathrm{~g}, 28 \mathrm{mmol})$ and phosphoryl trichloride $(6 \mathrm{~mL})$. The mixture was heated to $85^{\circ} \mathrm{C}$ for 50 
min. before cooling with ice bath (carefully, not frozen). Saturated sodium carbonate was added (slowly) until the $\mathrm{pH}$ reached 8 and the mixture was extracted with dichloromethane $(3 \times 30 \mathrm{~mL})$. The combined organic extracts was dried with sodium sulfate before celite was added and the mixture was concentrated in vacuo. Purification by DCVC $(\varnothing=40 \mathrm{~mm}$ ) gradient eluting from $100 \%$ toluene $\rightarrow 95 / 5$, toluene / acetonitrile with $1 \%$ increment / $50 \mathrm{~mL}$ fraction (each gradient run with $2 \times 50 \mathrm{~mL}$ ) yielded $0.61 \mathrm{~g} \mathrm{(48 \% )} 14$ as an uncoloured oil (the major side product was the $4^{\prime}$-chloro substituted analogue, not illustrated, of which was isolated $0.53 \mathrm{~g}(42 \%)) . R_{\mathrm{f}}=0.34\left(90 / 10\right.$, toluene / acetonitrile); $[\alpha]_{D}^{20}=+302^{\circ}\left(c=0.25, \mathrm{CHCl}_{3}\right)$; ${ }^{1} \mathrm{H} \mathrm{NMR}\left(400 \mathrm{MHz}, \mathrm{CDCl}_{3}\right) \delta 6.70\left(1 \mathrm{H}, \mathrm{t},{ }^{2} J_{\mathrm{HF}}=71.9 \mathrm{~Hz}\right), 6.45(1 \mathrm{H}, \mathrm{s}), 6.44(1 \mathrm{H}, \mathrm{s}), 3.97(3 \mathrm{H}, \mathrm{s}), 3.09(1 \mathrm{H}, \mathrm{dd}, J$ $=16.8$ \& $13.9 \mathrm{~Hz}), 2.99-2.87(1 \mathrm{H}, \mathrm{m}), 2.49(1 \mathrm{H}, \mathrm{dd}, J=16.6 \& 4.3 \mathrm{~Hz}), 0.99(3 \mathrm{H}, \mathrm{d}, J=6.7 \mathrm{~Hz}) ;{ }^{13} \mathrm{C} \mathrm{NMR}(101$ $\left.\mathrm{MHz}, \mathrm{CDCl}_{3}\right) \delta 194.4,191.8,169.7,157.1,156.4\left(\mathrm{t},{ }^{3} J_{\mathrm{CF}}=2.6 \mathrm{~Hz}\right), 151.8,131.7,115.3\left(\mathrm{t},{ }^{1} J_{\mathrm{CF}}=266 \mathrm{~Hz}\right), 108.7$, 101.8, 97.6, 91.9, 56.9, 40.1, 37.7, 15.1; ${ }^{19} \mathrm{~F} \mathrm{NMR}\left(282 \mathrm{MHz}, \mathrm{CDCl}_{3}\right) \delta-82.27\left(2 \mathrm{~F}, \mathrm{ABX}^{2} \mathrm{~J}_{\mathrm{FF}}=163.8 \mathrm{~Hz} \&{ }^{2} \mathrm{~J}_{\mathrm{FH}}=\right.$ $72.0 \mathrm{~Hz}) ; \mathrm{HRMS}\left(\mathrm{ESI}^{+}\right) 393.0104$ calcd. for $\left[\mathrm{M}+\mathrm{H}^{+}\right] 393.0103$.

\section{2-((( (2S,6'R)-7-Chloro-4,6-dimethoxy-6'-methyl-3-oxo-2'-phenoxy-3H-spiro[benzofuran-2,1'-cyclohexan]-} 2'-en-4'-ylidene)amino)oxy)acetic acid (16) ( $E / Z$ isomeric mixture). To a stirred solution of 2 (0.215 g, 0.50 $\mathrm{mmol}$ ) in ethanol $(12.5 \mathrm{~mL})$ and DMSO $(6.7 \mathrm{~mL})$ under argon, was added sodium acetate $(0.176 \mathrm{~g}$, $2.15 \mathrm{mmol}$ ) and (aminooxy)acetic acid hemihydrochloride $(0.191 \mathrm{~g}, 1.75 \mathrm{mmol})$. The mixture was heated to 65 으 for $20 \mathrm{hr}$. before cooling to $22^{\circ} \mathrm{C}$. Dichloromethane was added $(40 \mathrm{~mL})$ and the mixture was washed with water $(3 \times 25 \mathrm{~mL})$. The organic phase was dried with sodium sulfate before celite was added and the mixture was concentrated in vacuo. Purification by DCVC $(\varnothing=40 \mathrm{~mm})$ gradient eluting from $50 \%$ toluene $\rightarrow$ 60 / 40, toluene / acetonitrile (all solvents containing $0.5 \%$ acetic acid) with $4 \%$ increment / $50 \mathrm{~mL}$ fraction yielded $0.225 \mathrm{~g}(90 \%) 16$ as white crystals. $R_{\mathrm{f}}=0.23$ (59/39/2, toluene / acetonitrile / acetic acid); ${ }^{1} \mathrm{H}$ $\operatorname{NMR}\left(400 \mathrm{MHz}, \mathrm{CDCl}_{3}\right)$ 8 7.32-7.20 (3H, m), 7.20-7.12 (2H, m), $6.08(1 \mathrm{H}, \mathrm{s}), 5.65(6.28)(1 \mathrm{H}, \mathrm{s}), 4.88(4.96)$ $(1 \mathrm{H}, \mathrm{d}, J=12.3(12.2) \mathrm{Hz}), 4.77(4.82)(1 \mathrm{H}, \mathrm{d}, J=12.3(12.2) \mathrm{Hz}), 4.66-4.60(2 \mathrm{H}, \mathrm{m}), 4.01(3 \mathrm{H}, \mathrm{s}), 3.95(3 \mathrm{H}, \mathrm{s})$, $2.78(3.05)(1 \mathrm{H}, \mathrm{dd}, J=17.0(15.2) \& 13.0(13.4) \mathrm{Hz}), 2.70-2.54(1 \mathrm{H}, \mathrm{m}), 2.43(3.12)(1 \mathrm{H}, \mathrm{dd}, J=15.2(17.0)$ \& $4.2(4.9) \mathrm{Hz},), 0.97(0.98)(3 \mathrm{H}, \mathrm{d}, J=6.7(6.8) \mathrm{Hz}) ;{ }^{13} \mathrm{C} \mathrm{NMR}\left(101 \mathrm{MHz}, \mathrm{CDCl}_{3}\right) \delta 194.0$ (193.8), 174.4 (174.3), 169.7, 164.5, 158.7 (161.3), 157.7 (157.6), 157.1 (153.9), 135.7 (135.5), 128.5, 127.9 (128.0), 126.7 (126.8), 105.8 (105.7), 99.7 (94.1), 97.2 (97.2), (91.4) 91.4, (89.4) 89.4, 70.3 (70.2), (70.1) 70.1, (57.0) 57.0, 56.4, (36.5) 35.4, 26.4 (30.8), 14.5 (14.4); HRMS (ESI $\left.{ }^{+}\right) 502.1259$ calcd. for [M+H $\left.\mathrm{H}^{+}\right]$502.1263.

(2S,6'R)-7-Chloro-4,6-dimethoxy-2'-(methoxy-d3)-6'-methyl-3H-spiro[benzofuran-2,1'-cyclohexan]-2'-ene3,4'-dione (18). To a stirred solution of $17(0.20 \mathrm{~g}, 0.56 \mathrm{mmol})$ in 1,4-dioxane $(3 \mathrm{~mL})$ under argon was added deuterated methanol $(0.4 \mathrm{~mL})$ followed by DBU $\left(0.4 \mathrm{~mL}\right.$,). The solution was stirred at $22^{\circ} \mathrm{C}$ for 3 days. Celite was added and the mixture was concentrated in vacuo. Purification by DCVC $(\varnothing=20 \mathrm{~mm})$ gradient eluting from $100 \%$ heptane $\rightarrow 100 \%$ ethyl acetate with $10 \%$ increment $/ 25 \mathrm{~mL}$ fraction. The isolated compound $\left(R_{\mathrm{f}}=0.65\right.$ (ethyl acetate)) and $\mathrm{DBU}(0.4 \mathrm{~mL})$ were refluxed in $\mathrm{MeOH}(50 \mathrm{~mL})$ for $5 \mathrm{~h}$. The reaction mixture was left for 2 days at $22{ }^{\circ} \mathrm{C}$ were upon crystals of 18 was formed. Filtration yielded $170 \mathrm{mg}(85 \%) \mathbf{1 8}$ as a white powder, $R_{\mathrm{f}}=0.65$ (ethyl acetate); Mp. 217-219 ${ }^{\circ} \mathrm{C} ;{ }^{1} \mathrm{H}$ NMR $\left(400 \mathrm{MHz}, \mathrm{DMSO}-d_{6}\right) \delta 6.51(1 \mathrm{H}, \mathrm{s}), 5.61$ $(1 \mathrm{H}, \mathrm{s}), 4.05(3 \mathrm{H}, \mathrm{s}), 3.95(3 \mathrm{H}, \mathrm{s}), 2.88-2.74(1 \mathrm{H}, \mathrm{m}), 2.68(1 \mathrm{H}, \mathrm{dd}, J=16.4 \& 13.3 \mathrm{~Hz}), 2.36(1 \mathrm{H}, \mathrm{dd}, J=16.2$ \& $4.7 \mathrm{~Hz}), 0.81(3 \mathrm{H}, \mathrm{d}, J=6.7 \mathrm{~Hz}) ;{ }^{13} \mathrm{C}$ NMR $\left(101 \mathrm{MHz}\right.$, DMSO- $\left.d_{6}\right) \delta 196.0,191.6,170.7,169.0,164.9,158.1$, 105.1, 104.5, 95.7, 91.8, 90.6, 58.1, 57.1, 35.9, 14.3; HRMS (ESI $\left.{ }^{+}\right) 356.0975$ calcd. for $\left[\mathrm{M}+\mathrm{H}^{+}\right]$356.0979.

\section{Acknowledgements}


This work was supported by the Novo Nordisk Foundation, Biotechnology-based Synthesis and Production Research and Pre-seed Grants, as well as through an instrument grant from the Carlsberg Foundation. 


\section{References}

1 A. E. Oxford, H. Raistrick, P. Simonart, Biochem. J., 1939, 33, 240-248.

2 D. I. Williams, R. H. Marten, I. Sarkany, Lancet, 1958, 272, 1212-1213.

3 R. P. T. Davenport-Hines, J. Slinn, Glaxo: a History to 1962, Cambridge University Press, Cambridge, 1992, p 219.

4 A. B. Petersen, M. H. Rønnest, T. O. Larsen, M. H. Clausen, Chem. Rev. 2014, 114, 12088-12107.

5 Y.-S. Ho, J.-S. Duh, J.-H. Jeng,, Y.-J. Wang, Y.-C. Liang, C.-H. Lin, C.-J. Tseng, C.-F. Yu, R.-J. Chen, J.-K. Lin, Int. J. Cancer, 2001, 91, 393-401.

6 A. R. Chaudhuri, R. F. Ludueña, Drug Dev. Res., 2001, 53, 44-49.

7 R. A. B. Keates, Biochem. Biophys. Res. Commun., 1981, 102, 746-752.

8 T. Oda, J. Antibiot., 2006, 59, 114-116.

9 B. Rebacz, T. O. Larsen, M. H. Clausen, M. H. Rønnest, H. Löffler, A. D. Ho, A. Krämer, Cancer Res., 2007, 67, 63426350.

10 M. H. Rønnest, B. Rebacz, L. Markworth, A. H. Terp, T. O. Larsen, A. Krämer, M. H. Clausen, J. Med. Chem. 2009, 52, 3342-3347.

11 M. S. Raab, I. Breitkreutz, S. Anderhub, M. H. Rønnest, B. Leber, T. O. Larsen, L. Weiz, G. Konotop, P. J. Hayden, K. Podar, J. Fruehauf, F. Nissen, W. Mier, U. Haberkorn, A. D. Ho, H. Goldschmidt, K. C. Anderson, M. H. Clausen, A. Krämer, Cancer Res., 2012, 72, 5374-5385.

12 W. E. Barnette, CRC Crit. Rev. Biochem., 1984, 15, 201-235.

13 M. van Heek, C. F. France, D. S. Compton, R. L. McLeod, N. P. Yumibe, K. B. Alton, E. J. Sybertz, H. R. Davies Jr., J . Pharmacol. Exp. Therap., 1997, 283, 157-163.

14 J. W. Clader, J. Med. Chem., 2004, 47, 1-9.

15 S. Symchowicz, K. K. Wong, Biochem. Pharmacol., 1966, 15, 1595-1600.

16 P. A. Harris, S. Riegelman, J. Pharm. Sci., 1969, 58, 93-96.

17 C. Lin, R. Chang, J. Magat, S. Symchowicz, J. Pharm. Pharmacol., 1972, 24, 911-913.

18 C.-C. Lin, J. Magat, R. Chang, J. McGlotten, S. Symchowicz, J. Pharmacol. Exp. Ther., 1973, 187, 415-422.

19 M. H. Rønnest, M. S. Raab, S. Anderhub, S. Boesen, A. Krämer, T. O. Larsen, M. H. Clausen, J. Med. Chem. 2012, 55, 652-660.

20 T. Umemoto, K. Adachi, S. Ishihara, J. Org. Chem., 2007, 72, 6905-6917.

21 K. Stanek, R. Koller, A. Togni, J. Org. Chem., 2008, 73, 7678-7685.

22 R. Koller, K. Stanek, D. Stolz, R. Aardoom, K. Niedermann, A. Togni, Angew. Chem. Int. Ed., 2009, 48, $4332-4336$.

23 R. Ringom, T. Benneche, Acta Chem. Scand., 1999, 53, 41-47.

24 S. B. Christensen IV, S. Dabbs, J. M. Karpinski, 1996, PCT International Application WO/1996/023754.

25 S. Zheng, G. Kaur, H. Wang, M. Li, M. Yang, X. Macnaughtan, S. Reid, J. Prestegard, B. Wang, H. Ke, J. Med. Chem., 2008, 51, 7673-7688.

26 V. Arkley, J. Attenburrow, G. I. Gregory, T. Walker, J. Chem. Soc., 1962, 1260-1268.

27 L. Stephenson, T. Walker, W. K. Warburton, G. B. Webb, J.Chem. Soc., 1962, 1282-1292.

28 For an example of a small-scale protocol for direct position-6 demethylation, see: M. H. Rønnest, P. Harris, C. H. Gotfredsen, T. O. Larsen, M. H. Clausen, Tetrahedron Lett., 2010, 51, 5881-5882.

29 J. A. Erickson, J. I. McLoughlin, J. Org. Chem., 1995, 60, 1626-1631.

30 F. Narjes, K. F. Koehler, U. Koch, B. Gerlach, S. Colarusso, C. Steinkühler, M. Brunetti, S. Altamura, R. De Francesco, V. G. Matassa, Bioorg. Med. Chem. Lett., 2002, 12, 701-704.

31 N. A. Meanwell, J. Med. Chem., 2011, 54, 2529-2591.

32 D. S. Pedersen, C. Rosenbohm, Synthesis 2001, 16, 2431-2434. 